\title{
Edmodo-Based Interactive Teaching Materials as an Alternative Media for Science Learning to Improve Critical Thinking Skills of Junior High School Students
}

\author{
https://doi.org/10.3991/ijim.v14i09.13041 \\ Sri Wahyuni \\ Universitas Negeri Surabaya, Surabaya, Indonesia \\ Universitas Jember, Jember, Indonesia \\ Erman, Setya Yuwana Sudikan, Budi Jatmiko $(\bowtie)$ \\ Universitas Negeri Surabaya, Surabaya, Indonesia \\ budijatmiko@unesa.ac.id
}

\begin{abstract}
This study aims to develop edmodo-based interactive teaching materials as an alternative media for science learning to improve critical thinking skills of junior high school students. This type of research is Research and Development (R\&D) with ADDIE (Analyze, Design, Development, Implementation, and Evaluation) models. The research subjects were 28 students of grade VII in Jember district (Indonesia) who were obtained by cluster random sampling technique. Data were collected using validation sheets, observation sheets, critical thinking skills tests, and students responses questionnaires. Data were analyzed using descriptive analysis, normalized gain (n-gain), and paired sample ttest. The results show that edmodo-based interactive teaching materials can be used as an alternative media for learning science in junior high schools because they meet the following criteria: (1) validity, in terms of the validity assessment score of 3.60 (from the range of scores from 0 to 4 ) in the criteria are very valid, (2) practicality, in terms of the score of learning feasibility of 3.20 in good criteria, (3) effectiveness, in terms of an increase students critical thinking skills were statistically significant at $\alpha=5 \%$ with an average n-gain of .71 in high criteria, and student responses of $83 \%$ in very good criteria.
\end{abstract}

Keywords-Interactive teaching materials; edmodo; critical thinking skills.

\section{Introduction}

In 2014, Indonesia began to introduce Computer-Based National Exam (CBNE), also called the Computer-Based Test (CBT), which is a system of implementing national exams using computers as the test media [1]. The computer-based assessment system is expected to improve the security system when conducting national examinations, so as to minimize all forms of fraud [2]. Not only in Indonesia, various countries have also implemented a computer-based assessment system or CBT, for example in America, Sri Lanka, and Nigeria [3, 4, 5]. The results of observations related 
to students' readiness to face the assessment system in the form of CBNE, showed that there are still many students who need high concentration when working on problems in front of a computer screen that emits light so that it affects eye performance and concentration [6]. In addition, someone's reading speed on paper is $20 \%$ faster than on a computer screen [7]. That is because the comparison of reading on paper with reading on a computer screen certainly gives more side effects to the eyes, i.e. when looking at the monitor for a long time accompanied by full concentration will cause fatigue in the eyes [8].

CBNE results for middle school students in 2017 decreased, especially the results of national examinations in schools that switched from Paper and Pencil-Based National Exam (PBNE) to CBNE [9]. In contrast to the results of research conducted by Seoul National University, South Korea which shows that the CBNE results are no different from PBNE in language skills [10]. While research conducted in Germany actually gives very different results, each student has a different understanding in operating a computer that raises its own concerns in students which results in different results obtained [11]. The same thing also happens in Indonesia, that students have increased concerns when facing CBNE, especially when calculating lessons such as mathematics and science [12]. Therefore, schools that rarely use online learning need to get used to their students to take part in online learning both in the form of learning processes, communication using social media, and the assessment system.

Based on the results of interviews with several science teachers in Jember (Indonesia), it shows that most students have difficulty understanding conceptual learning material so that interactive teaching materials are needed in the form of example problems, question exercises, or other media such as pictures and videos. This is consistent with the results of the questionnaire given to students, which shows that $70 \%$ of students said they rarely use technology-based teaching materials, such as smartphones even though $85 \%$ of students have smartphones, students feel there is a dependence on technology by $60 \%$, and students use smartphones to play games by $50 \%$. Based on the results of interviews and questionnaires showed that students need technology-based teaching materials that can support learning activities, especially among the younger generation such as junior high schools who mostly have smartphones.

Based on the results of studies that have been conducted on several website applications that can be utilized in 21 st century learning, including:

1. Edmodo $[13,14]$

2. Moodle [15]

3. Google Classroom, Google Drive, Google Docs [16]

4. $\mathrm{B} \log$ [17]

5. Kidblog [18]

6. Wikispaces [19]

7. Classkick and Seesaw [20]

Show that the application with edmodo is a social media platform that resembles facebook, so it is easy to use and better known by teachers and students compared to other applications [21]. Edmodo is a social platform specifically developed and 
designed for use by teachers and students in a classroom, making them feel safer and easier to communicate and collaborate, sharing content in the form of text, images, links, videos, audio, Homework for students, discussions in virtual classrooms, online quizzes, and can assess automatically, and there are facilities for parents to be able to monitor all their children's activities on edmodo by logging in using parent code [22].

Edmodo-based learning can be a breakthrough for schools that rarely use online learning. The use of various teaching materials and learning media in the form of print that has been used actually has been able to assist students in finding and understanding learning concepts, but the printed form is not interactive, sometimes left behind, or even lost. To overcome the shortcomings of teaching materials and printed learning media, it is necessary to develop other forms of teaching materials, one of which is edmodo.

Edmodo-based interactive teaching materials are considered interesting and make it easier for students to learn subject matter, because these teaching materials can be applied to various learning models that help students process information, analyze, and synthesize problems encountered in daily life to improve students' critical thinking skills. Therefore, the purpose of this study is to develop edmodo-based interactive teaching materials as an alternative science learning media to improve the critical thinking skills of junior high school students.

\section{Overview}

\subsection{Interactive teaching materials}

Teaching material is material or subject matter arranged systematically, which is used by teachers and students in the learning process. Teaching materials are all forms of materials used to assist teachers in carrying out teaching and learning activities, where the material referred to may be written or unwritten material [23]. Teaching material is a set of material that is arranged systematically, displaying the ability to be mastered by students in learning activities [24]. Teaching materials are all materials (both information, tools, and texts) that are arranged systematically, which displays the abilities students will master and use in the learning process. Teaching materials can be in the form of textbooks, modules, handouts, student activity sheets, audio teaching materials, and interactive teaching materials [25].

Interactive teaching materials are a combination of two or more media (audio, text, graphics, images, animation, and video) that the user is treated with. The structure of interactive teaching materials consists of six components, namely titles, study instructions, basic competencies or subject matter, supporting information, exercises, and assessments [26]. There are several ways that can be done in the preparation of interactive teaching materials, namely:

1. Possess adequate supporting knowledge and skills, especially in operating equipment such as computers, videos and photographs.

2. Interactive teaching materials can be presented in the form of compact disks.

3. There is a title of basic competency or material. 
4. Write instructions for learning.

5. Explain supporting information in a clear, concise and attractive manner in written form or still or motion pictures.

6. Writing tasks in an interactive form.

7. Evaluating the work of the assignment can be seen by the teacher through a computer.

8. Uses various learning resources that can enrich the material, for example books, magazines, internet, and research journals as material in making interactive teaching materials [27].

\subsection{Critical thinking skills}

Critical thinking is the process by which all knowledge and skills are mobilized in solving problems that arise, making decisions, analyzing all assumptions that arise, conducting investigations or research based on data and information that has been obtained to produce scientific information or conclusions. John Dewey argued that critical thinking characterizes a person thinking things in depth, asking various questions, finding relevant information rather than waiting for information passively [28]. The characteristics of someone said to think critically are:

1. Able to analyze the subject matter in the subject matter well.

2. Able to describe the condition of the problem being discussed.

3. Able to express explicitly the subject matter.

4. Polite and polite in expressing opinions, asking and answering questions.

5. Like asking questions and answering questions in learning activities.

6. Sensitive to situations and conditions of learning that are taking place.

7. Have a strong curiosity.

8. Do not easily give up or despair about learning problems in the classroom.

9. Able to use spoken language in a way varied and interesting to hear.

10. Able to communicate smoothly and enthusiastically [29].

Indicators of critical thinking skills consist of the skills to identify relationships between sections, evaluation skills, the ability to distinguish various arguments or solutions to a problem in the sense of being able to distinguish strong and relevant arguments from weak or irrelevant to specific questions of a problem, and inference skills or skills draw general conclusions by examining individual cases and differentiating between various data sources [30].

Based on these descriptions, indicators of critical thinking skills used in this study are shown in Table 1. 
Table 1. Indicators of critical thinking skills

\begin{tabular}{|c|l|l|}
\hline No. & \multicolumn{1}{|c|}{$\begin{array}{c}\text { Indicators of Critical } \\
\text { Thinking Skills }\end{array}$} & \multicolumn{1}{c|}{ Remarks } \\
\hline 1. & Actual & $\begin{array}{l}\text { Fact analysis: analyzing the meaning of the facts } \\
\text { presented in the problem correctly and honestly }\end{array}$ \\
\hline 2. & Reason & $\begin{array}{l}\text { Submission of reason: organizing thoughts and express } \\
\text { reasons clearly, logically or reasonably. }\end{array}$ \\
\hline 3. & Argumentation & $\begin{array}{l}\text { Submission of arguments: denying an irrelevant } \\
\text { argument and deliver relevant arguments }\end{array}$ \\
\hline 4. & Inference & $\begin{array}{l}\text { Conclusion: distinguishing between conclusions based } \\
\text { on valid logic and invalid logic }\end{array}$ \\
\hline 5. & Implication & $\begin{array}{l}\text { Presentation of implications: questioning a view and the } \\
\text { implications of a view }\end{array}$ \\
\hline
\end{tabular}

Source: Adoption of Facione [29]

\section{Methodology}

\subsection{Research design}

This study is a development research with ADDIE (Analyze, Design, Development, Implementation, and Evaluation) model. The product developed is edmodo-based teaching materials on the subject of temperature and heat in natural science grade VII subjects odd semester 2019/2020.

\subsection{Participants}

The population of this study is all grade VII students at public junior high school 3 Jember. Sampling was carried out by cluster random sampling technique, so that one grade VIIB was selected as a model testing group of 28 students.

\subsection{Instrument}

The research instruments used included: validation sheets, observation sheets, critical thinking skills tests, and student response questionnaires.

Validation sheet: The validation sheet was developed theoretically as a validator's guideline to assess the quality of edmodo-based interactive teaching materials consisting of: the appropriateness of the contents of the material, ease of use of language, presentation of material in accordance with student character, design, and speed in opening and running the material. Validation of edmodo-based interactive teaching materials is done through Focus Group Discussion (FGD) activities.

Observation sheet: The observation sheet was developed theoretically as an observer's guideline to assess the feasibility of guided inquiry model teaching using edmodo-based interactive teaching materials, with indicators consisting of: the 
implementation of the guided inquiry model syntax, classroom atmosphere, and time management. The score of the teaching performance was obtained from the evaluation of three observers.

Critical thinking skills test: Critical thinking skills test instrument in the form of essay tests compiled based on indicators of critical thinking skills consists of 25 items and has been validated by 3 experts, both in terms of aspects of content validity, language, and in terms of writing questions.

Student response questionnaires: Student response questionnaire instrument was given after the entire learning process was complete. Response questionnaire aims to find out the students' responses to the learning of guided inquiry models using interactive learning materials based on Edmodo. Questionnaire responses in the form of student questionnaires in the form of statements using a Likert scale. The scoring rubric uses a range of scores from 1 to 4 , with a score of $1=\operatorname{not}$ good, $2=$ poor, $3=$ good, 4 = very good. The quality of student response questionnaires is determined through validation by 3 experts.

\subsection{Data analysis}

Analysis of the data in this study includes: analysis of the validity, practicality, and effectiveness of interactive teaching materials based on Edmodo.

Validity: The validity of edmodo-based interactive teaching materials was obtained from the assessment of three validators using a validity assessment instrument that refers to the criteria in Table 2.

Table 2. Criteria for Edmodo-based interactive teaching material validation

\begin{tabular}{|c|l|l|}
\hline Score & \multicolumn{1}{|c|}{ Criteria } & \multicolumn{1}{c|}{ Remarks } \\
\hline $3.25<$ Score $\leq 4.00$ & Very Valid & Can be used without revision \\
\hline $2.50<$ Score $\leq 3.25$ & Valid & Can be used with some revisions \\
\hline $1.75<$ Score $\leq 2.50$ & Less Valid & Can be used with many revisions \\
\hline $1.00<$ Score $\leq 1.75$ & Invalid & Not used yet and still requires consultation \\
\hline
\end{tabular}

Source : Adoption of Ratumanan \& Laurens [31]

Reliability of the results of evaluating the validity of the Edmodo-based interactive teaching material is calculated based on the percentage of agreement formula as follows:

$$
\text { Percentage of Agreement }(R)=\left[1-\frac{A-B}{A+B}\right] X 100 \%
$$

Remarks:

R: Inter-observer agreement coefficient.

A: Validator assessment that gives high marks.

B: Validator assessment that gives low marks.

The results of the validity assessment of the Edmodo-based interactive teaching materials are said to be reliable, if obtained percentage of agreement $\geq 75 \%$. 
Practicality: The practicality of edmodo-based interactive teaching materials is a good measure of whether or not the feasibility of learning is obtained from observers by giving an interval score of 1 to 4 . The assessment criteria are obtained by calculating the mean assessment scores given by each observer with the criteria as shown in Table 3 .

Table 3. Criteria for the Score of Learning Feasibility

\begin{tabular}{|c|l|}
\hline \multicolumn{1}{|c|}{ Score } & \multicolumn{1}{c|}{ Criteria } \\
\hline $3.25<$ Score $\leq 4.00$ & Very good \\
\hline $2.50<$ Score $\leq 3.25$ & Good \\
\hline $1.75<$ Score $\leq 2.50$ & Poor \\
\hline $1.00<$ Score $\leq 1.75$ & Not Good \\
\hline
\end{tabular}

Source : Adoption of Ratumanan \& Laurens [31]

Effectiveness: Analysis of the effectiveness of edmodo-based interactive teaching material data is obtained from the analysis of critical thinking skills data and student responses. The level of improvement in critical thinking skills is calculated using normalized gain (n-gain) from pre-test and post-test with the formula:

$$
\mathrm{n} \text {-gain }=\frac{\text { Final Test Score }- \text { Initial Test Score }}{\text { Maximum Score }- \text { Initial Test Scor }}
$$

n-gain criteria as shown in Table 4.

Table 4. Normalized gain (n-gain) criteria

\begin{tabular}{|c|l|}
\hline Score & \multicolumn{1}{c|}{ Criteria } \\
\hline $.70<$ n-gain & High \\
\hline $.30 \leq$ n-gain $\leq .70$ & Moderate \\
\hline n-gain $<.30$ & Low \\
\hline
\end{tabular}

Source: Meltzer [33]

To find out if there are differences in pre-test and post-test scores after using edmodo-based interactive teaching materials, paired Sample t-test was used. The difference between pre-test and post-test scores on critical thinking skills is used to describe the existence of a significant impact on the application of edmodo-based interactive teaching materials. Paired sample t-test test data analysis techniques were performed using SPSS version 20 statistical tools. Assumptions tests that must be met before a paired sample t-test is used are normality and homogeneity tests [34].

Data about student responses was obtained from student questionnaire responses to learning activities, and then analyzed using quantitative and qualitative descriptive. Analysis of student response questionnaire data used a Likkert scale in the form of positive questions.

$$
\mathrm{P}=\frac{\sum \mathrm{K}}{\sum \mathrm{N}} \times 100 \%
$$


Remarks:

P: percentage of student response scores

$\sum \mathrm{R}$ : the number of scores achieved by students

$\sum \mathrm{N}$ : the number of highest scores a student might achieve

\section{$4 \quad$ Finding and Discussion}

\subsection{Edmodo-based interactive teaching materials}

The teaching material developed in this study is edmodo-based interactive teaching material on the temperature and heat content of grade VII middle school using the ADDIE model. ADDIE model is one model of developing a valid, practical, and effective learning tool with 5 stages as follows [35]:

Analysis: At this stage a literature review and interview is carried out related to the use of teaching materials in schools, both sourced from national and international journals. In modern times with the rapid development of technology and information, teacher professionalism is not enough just to deliver teaching materials to students, but also must manage information and the environment to facilitate student learning processes, one of which is to enrich learning resources [36]. Based on the results of interviews with teachers, stated that the teacher had felt enough to use a blackboard, markers, and textbooks as teaching material, for several reasons including: lack of funds and inadequate infrastructure. The funding factor is an obstacle for most teachers, as if the existence of an interactive teaching material always requires funding. Whereas interactive teaching material is not always about funding, but depends on the creative skills of a teacher to address the problem of teaching materials by utilizing technology [37]. Based on the results of the analysis, it can be said that teaching materials commonly used by teachers are limited to textbooks distributed from the government. Therefore, an innovation in teaching materials is needed that can make it easier for students to understand the material so that they can improve critical thinking skills which are the demands of the 21 st century.

Design: At this stage the researchers designed the initial design of interactive teaching materials based on consideration of several factors, namely: a). curriculum used in schools, b). interactive teaching materials applications that are developed must meet the specifications: (1) easy to use, (2) easy in the installation process, (3) in accordance with the material at school, c). compile material that can train students' critical thinking skills. In addition to edmodo-based interactive teaching materials, researchers also developed learning devices designed in accordance with the 2013 revised curriculum on temperature and heat material.

Development: At this stage edmodo-based interactive teaching materials are developed in accordance with the designs that have been made in the previous stage. At the development stage an edmodo-based interactive teaching material prototype is shown in Figure 1. 


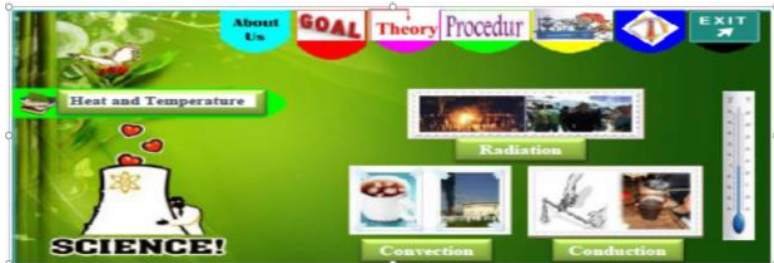

Fig. 1. Prototype of Interactive Edmodo-Based Teaching Materials.

Implementation: In the implementation phase, an interactive Edmodo-based teaching material was tested in the classroom using a guided inquiry model that was in accordance with the 2013 curriculum to illustrate the implementation of the teaching and learning process both in terms of teaching activities undertaken by teachers and learning activities by students observed by three observers. The aim of using this guided inquiry model is to develop thinking skills in a systematic, logical and critical manner that is compatible with edmodo-based interactive teaching materials.

Evaluation: At the evaluation stage, students are given a test of critical thinking skills. The assessment sheet of the critical thinking skills test instrument before use, is first validated by experts from the aspect of content validity and aspects of language validity. The results of the validity assessment show that the critical thinking skills test instrument scores are in the range of $3.00-4.00$ in the criteria of very valid and valid with a reliability value of $86 \%-100 \%$. This shows that the critical thinking skills test instrument developed is appropriate to be used to measure students' critical thinking skills. Characteristics of a good instrument other than valid are reliable meaning that the instrument, if used several times to measure the same object, will produce the same data [38].

\subsection{Validity}

The prototype of edmodo-based interactive teaching materials that have been produced is validated through Focus Group Discussion (FGD), with the consideration that:

1. Validation of a product can be done through FGD by experts, both face to face and online [39].

2. FGD, there are three important things, namely: the process of gathering information, the discussion is focused on a particular topic, and participants come from experts in their fields [40].

The edmodo-based interactive teaching material validator consists of three science education experts. The validation (filling in the validation instrument) was carried out by experts after the suggestions given during the FGD. The validation data are presented in Table 5. 
Paper-Edmodo-Based Interactive Teaching Materials as an Alternative Media for Science Learning ...

Table 5. Results of Edmodo-Based Interactive Teaching Validity Assessment

\begin{tabular}{|l|c|c|c|l|}
\hline \multicolumn{1}{|c|}{ Assessment Aspects } & \multicolumn{2}{c|}{ Validity } & \multicolumn{2}{c|}{ Reliability } \\
\cline { 2 - 4 } & Score & \multicolumn{1}{c|}{ Criteria } & $\boldsymbol{R}(\%)$ & \multicolumn{1}{c|}{ Criteria } \\
\hline The feasibility of the contents of the material is in & & & & \\
accordance with the students intellectual development & & & & \\
Ease of use of language & 4.00 & Very Valid & 100 & Reliable \\
Presentation of material in accordance with the & 3.00 & Valid & 100 & Reliable \\
character of students & 4.00 & Very Valid & 100 & Reliable \\
Graphic design of edmodo-based interactive teaching & 4.00 & Very Valid & 100 & Reliable \\
materials & 3.00 & Valid & 86 & Reliable \\
The speed of opening and running edmodo-based & & & & \\
interactive teaching materials & & & & \\
\hline Average & 3.60 & Very Valid & 97.20 & Reliable \\
\hline
\end{tabular}

Remarks: $\mathrm{R}=$ Inter observer agreement coefficient

The results of the validator assessment showed that the validity score of edmodobased interactive teaching materials was 3.60 (from the score range 1-4) in the very valid criteria. The reliability coefficient on the aspect of evaluating the validity of edmodo-based interactive teaching materials is $97.20 \%$. Based on the interobserver agreement, the reliability coefficient of edmodo-based interactive teaching materials is above $75 \%$, so it is included in the reliable criteria.In addition edmodo-based interactive teaching materials are also revised based on suggestions from the validator including in terms of writing, presentation of material, and graphics. Based on the writing aspect, namely the use of capital letters and typos, the presentation and graphic terms are to change the color of the design to be brighter, choose the correct type and concept in the animation and the size of the letters is more varied and interesting.

\subsection{Practicality}

The practicality of edmodo-based interactive teaching materials illustrates the feasibility of the teaching-learning process both seen from the teaching activities carried out by the teacher and learning activities by students during the teaching-learning process with the guidance of the teacher obtained from the assessment of three observers. Data on the implementation of teaching at the time of implementation is shown in Figure 2. 


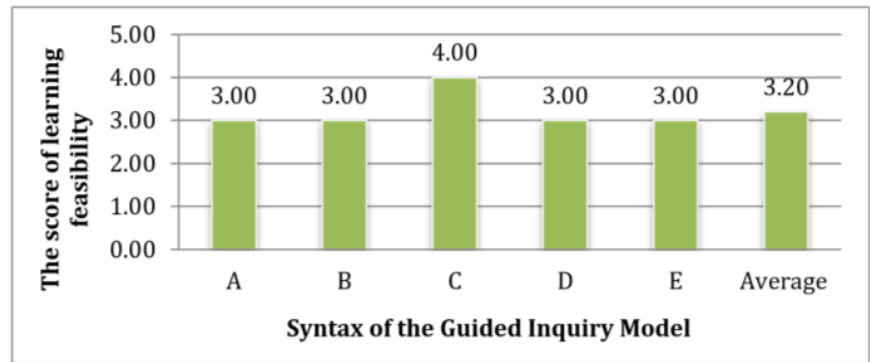

Remarks: $A=$ Phase 1: Identification and determination of the scope of the problem $\mathrm{B}=$ Phase 2: Planning and predicting experiments

$\mathrm{C}=$ Phase 3: Investigation and data collection

$\mathrm{D}=$ Phase 4: Data interpretation and conclusion development

$\mathrm{E}=$ Phase 5: Reflection

Fig. 2. The Implementation of the Guided Inquiry Model using Edmodo-based Interactive Teaching Materials

Figure 2 shows that the data on the implementation of guided inquiry models using edmodo-based interactive teaching materials are included in good and reliable criteria with a mean score of 3.20. This shows that the design of the steps of guided inquiry learning model using edmodo-based interactive teaching materials can be implemented well to improve the critical thinking skills of junior high school students.

In reality in the practice of education many educators still use teaching materials that are already available without checking their eligibility so that the impact that the teaching materials they use are not contextual, unattractive, monotonous, and not in accordance with the needs of students [41]. One type of technological innovation in teaching materials that can be used in schools is interactive teaching materials. Interactive teaching material is an independent learning package that includes a series of learning experiences that are planned and systematically designed to help students achieve learning goals.

\subsection{Effectiveness}

The effectiveness of edmodo-based interactive teaching materials illustrates the impact of the application of teaching materials developed to improving students critical thinking skills. Effectiveness of edmodo-based interactive teaching material data is in terms of improving critical thinking skills and student responses. Data on critical thinking skills from the pre-test and post-test results are presented in Table 6. 
Table 6. Pre-test and Post-test Critical Thinking Skill Descriptions

\begin{tabular}{|l|c|c|c|l|}
\hline \multicolumn{1}{|c|}{ Indicators of Critical Thinking Skills } & Pre-test & Post-test & n-gain & Criteria \\
\hline Actual & 52 & 75 & .77 & High \\
\hline Reason & 50 & 74 & .75 & High \\
\hline Argumentation & 38 & 68 & .68 & Moderate \\
\hline Inference & 45 & 74 & .78 & High \\
\hline Implication & 40 & 63 & .55 & Moderate \\
\hline Average
\end{tabular}

Table 6 shows that the average n-gain of critical thinking skills in teaching and learning activities by applying edmodo-based interactive teaching materials is .71 in the High criteria. This shows that edmodo-based interactive teaching materials on the material temperature and heat is something new so it becomes interesting to use in learning, because student learning activities involve the role of smartphones that can be accessed by students anytime offline or online. Teaching material developed is interactive teaching material, so that with a higher level of concrete message can improve students critical thinking skills [42].

Then the significance test of the pre-test and post-test data is performed to determine whether there is an increase in students critical thinking skills using the paired sample t-test. Statistical tests of assumptions that must be met before the paired sample t-test are normality and homogeneity tests. Based on the results of normality, homogeneity, and paired sample t-test using SPSS 20 software are presented in Table 7.

Table 7. Statistical Tests Result on Critical Thinking Skills Tests

\begin{tabular}{|c|c|c|c|c|c|c|}
\hline \multicolumn{1}{r|}{ Statistical Test } & N & Mean & S & df & t & p \\
\hline Pre-test -Post-test & 28 & -2.46 & -.71 & 27 & -21.99 & $<.0001$ \\
\hline
\end{tabular}

$* \mathrm{p}<.05$ (2-tailed)

Based on Table 7 shows that $\mathrm{t}$ is negative, then edmodo-based interactive teaching materials have an impact on increasing students critical thinking skills at a $5 \%$ significance level. These results are in line with research on the development of interactive teaching materials that are designed to improve students critical thinking skills, where one of the advantages of using Edmodo has the potential to enhance a more meaningful learning experience, so as to improve students critical thinking skills [43].

At the end of the lesson, students are asked to fill in a response questionnaire that aims to determine student responses to edmodo-based interactive teaching materials. This student response questionnaire is needed to find out student responses in the field and to find out the advantages and disadvantages of edmodo-based interactive teaching materials from the student's perspective even though they have been validated by experts as shown in Table 8. 
Table 8. Student Responses Assessment Results

\begin{tabular}{|c|l|c|c|}
\hline No. & \multicolumn{1}{|c|}{ Statement } & \multicolumn{1}{|c|}{ Responses } \\
\cline { 3 - 4 } 1. & $\begin{array}{l}\text { Edmodo-based interactive teaching materials are very interesting } \\
\text { because they can be used face-to-face or online. }\end{array}$ & 85 & Very good \\
\hline 2. & $\begin{array}{l}\text { The language contained in edmodo-based interactive teaching } \\
\text { materials is easy to understand }\end{array}$ & 85 & Very good \\
\hline 3. & $\begin{array}{l}\text { The material contained in edmodo-based interactive teaching } \\
\text { materials is easy to understand }\end{array}$ & 80 & Very good \\
\hline 4. & $\begin{array}{l}\text { The tools and materials contained in edmodo-based interactive } \\
\text { teaching materials are very interactive }\end{array}$ & 86 & Very good \\
\hline 5. & $\begin{array}{l}\text { Exercises contained in Edmodo based interactive teaching materials } \\
\text { easy to understand }\end{array}$ & 75 & Good \\
\hline 6. & $\begin{array}{l}\text { The writing, pictures, and graphics contained in edmodo-based } \\
\text { interactive teaching materials are very appropriate }\end{array}$ & 85 & Very good \\
\hline 7. & $\begin{array}{l}\text { I am very happy if the next learning process uses edmodo-based } \\
\text { interactive teaching materials. }\end{array}$ & 88 & Very good \\
\hline Average & \multicolumn{1}{|c|}{83} & Very good \\
\hline
\end{tabular}

Based on Table 8, the results of the assessment of student responses showed that the average percentage obtained was $83 \%$ with very good criteria.

\section{Conclusion}

Based on the results of data analysis and discussion, it can be concluded that edmodo-based interactive teaching materials on temperature and heat material meet the following criteria:

1. Validity, because it has a validity value of 3.60 in very valid criteria.

2. Practicality, because teachers are able to implement edmodo-based interactive teaching materials in good and reliable criteria with a mean score of 3.20

3. Effectiveness, because there is an increase in skills critical thinking of students is statistically significant at $\alpha=5 \%$, with an average n-gain of .71 in high criteria, and obtains student responses during learning with an average percentage of $83 \%$ in very good criteria. Thus, edmodo-based interactive teaching materials can be used as alternative media for learning science to improve critical thinking skills of junior high school students.

\section{Acknowledgement}

The author's gratitude goes to the Ministry of Research, Technology and Higher Education for financial assistance through the Domestic Postgraduate Program Scholarship (BPPDN) for 2017-2020. Likewise, the author's gratitude goes to Universitas Negeri Surabaya and Universitas Jember that have provided research opportunities. 


\section{$7 \quad$ References}

[1] Hidayah, N. (2013). National examination in public policy perspective. Jurnal Pencerahan, $7(1), 35-40$.

[2] Ningsih, S. K, Herri, M. (2019). Digital Assessment Resources in Primary and Secondary School Classrooms Teachers' Use and Perceptions.International Journal of Interactive Mobile Technologies (iJIM), 13(8), 167-173. https://doi.org/10.3991/ijim.v13i08. 10730.

[3] Russell, M., Goldberg, A., \& O'connor, K. (2003). Computer-based testing and validity: a look back into the future. Assessment in Education, 10(3), 279-293. https://doi.org/10. $\underline{1080 / 0969594032000148145}$

[4] Arachchi, S. M., Dias, K., \& Madanayake, R. S. (2014). A comparison between evaluation of computer-based testing and paper-based testing for subjects in computer programming. International Journal of Software Engineering \& Applications (IJSEA), 5(1), 5772.https://doi.org/10.5121/ijsea.2014.5105

[5] Jimoh, R.G., Shittu, A. J. K., \& Kawu. (2012). Students' perception of Computer Based Test (CBT) for examining undergraduate chemistry courses. Journal of Emerging Trends in Computing and Information Sciences, 3(2), 125-134.

[6] Kusaeri, K. (2017). Cheating behavior study of madrasa students and islamic schools when national exams. Edukasia: Jurnal Penelitian Pendidikan Islam, 11(2), 331354.https://doi.org/10.21043/edukasia.v11i2.1727

[7] Garland, K. J., \& Noyes, J. M. (2003). VDT versus paper-based text: reply to mayes, sims and koonc. International Journal of Industrial Ergonomics, 31, 411-423. https://doi.org/10.1016/s0169-8141(03)00027-1

[8] Suryadi, D. (2016). Effects of monitor radiation on eye health. Jurnal Nasional Ecopedon, 3(1), 140-143.

[9] Harmiyuni \& Sailan, M. (2016). Students' perceptions about the implementation of the Computer-Based National Exam at the vocational school of Mutiara Ilmu Makassar. Jurnal Tomalebbi, 3(2), 36-42.

[10] Choi, I. C., Kim, K. S., \& Boo, J. (2015). Comparability of a paper-based language test and a computer-based language test. Nova Southeastern Univ, 20(3), 295320.https://doi.org/10.1191/02655322031t258oa

[11] Karay, Y., Schauber, S. K., Stosch, C., \& Brauns, K. S. (2015). Computer versus paper does it make any difference in test performance? Teaching and Learning in Medicine, 27(1), 5762. https://doi.org/10.1080/10401334.2014.979175

[12] Sulistyaningsih, E., \& Sugiman, S. (2016). The effect of CBT national examination on senior high school students's cognitive readiness and anxiety facing mathematics tests in DIY Province. Jurnal Riset Pendidikan Matematika, 3(2), 198-208. https://doi.org/10. 21831/jrpm.v3i2.10868

[13] Al-Said, K.M. (2015). Students' perceptions of edmodo and mobile learning and their real barriers towards them. TOJET: The Turkish Online Journal of Educational Technology, 14(2), 168-183.

[14] Sorensen, C. (2015). An Examination of the relationship between online class size and instructor performance. Journal of Educators Online, 12(1), 140-159. https://doi.org/10. 9743/jeo.2015.1.3

[15] Kaya M \& Ozel, S A. (2014). Integrating an online compiler and a plagiarism detection tool into the moodle distance education system for easy assessment of programming assignments. Computer Applications in Engineering Education, 23(3), 363-373. 
[16] Marzal, J. (2014). Studies on the use of edmodo social networks as e-learning media by senior lecturers not accustomed to working with computers. Edumatica, 4(1), 38.

[17] Kingsley, Karla V. \& Brinkerhoff, J. (2011). Web 2.0 tools for authentic instruction, learning, and assessment. Social Studies and the Young Learner, 23(3), 9-12.

[18] Richardson, W. (2006). Blogs, wikis, podcasts, and other powerful web tools for classrooms. Thousand Oaks, California: Corwin Press. https://doi.org/10.1177/0162643408023 $\underline{00207}$

[19] Suartama, I.K, Punaji, S., Sulthoni, Saida, U. (2019). Development of an instructional design model for mobile blended learning in higher education. International Journal of Emerging Technologies in Learning (iJET), 14(16), 4-22. https://doi.org/10.3991/ijet.v14i16. 10633.

[20] Fawareh, H. M. A., Shaidah J. (2017). The use and effects of smartphones in higher education. International Journal of Interactive Mobile Technologies (iJIM), 11(6), 103-111. https://doi.org/10.3991/ijim.v11i6.7453.

[21] Hamann, K., Pollock, P. H., \& Wilson, B. M. (2012). Assessing student perceptions of the benefits of discussions in small-group, large-class, and online learning contexts. College Teaching, 60(2), 65-75. https://doi.org/10.1080/87567555.2011.633407

[22] Suana, W. N. Maharta1, I D. P. Nyeneng1, S. Wahyuni. (2017). Design and implementation of schoology based blended learning media for basic physics 1 course. Jurnal Pendidikan IPA Indonesia, 6(1), 170-178. https://doi.org/10.15294/jpii.v6i1.8648

[23] Majid, A. (2006). Learning Planning. Bandung: Rosdakarya.

[24] Heinich, R., Molenda, M., Russell, J. D., \& Smaldino, S. E. (2002). Instructional media and technology for learning, 7th edition. New Jersey: Pearson education, Inc.

[25] Prastowo, A. (2012). Creative guide to making innovative teaching materials. Yogyakarta: DIVA Press.

[26] Depdiknas. (2006). Guidelines for choosing and arranging teaching materials. Jakarta: Direktorat Sekolah Menengah Pertama.

[27] Selwyn, N. (2009). Faceworking: exploring students' education-eelated use of facebook. Learning, Media and Technology, 34 (2), 157-174. https://doi.org/10.1080/ 17439880902923622

[28] Fisher, A. (2009). Critical thinking: an introduction. Jakarta: Erlangga.

[29] Facione, P. A. (2015). Critical thinking: what it is and why it counts. insight assessment. California: California Academic Press.

[30] Gillies, R. (2011). Promoting thinking, problem-solving, and reasoning during small group discussions. Teachers and Teaching: Theory and Practice, 17, 73-89. https://doi.org/10. $\underline{1080 / 13540602.2011 .538498}$

[31] Ratumanan, G.T. \& Laurens. (2011). Evaluate results that are relevant to solving learning and teaching problems. Bandung: CV Alfabeta.

[32] Borich, G. D. (1994). Observation skills for effective Teaching. New York: MacMillan Publishing Company. https://doi.org/10.1119/1.1514215

[33] Meltzer, D. E. (2002). The relationship between mathematics preparation and conceptual learning gains in physics: A possible hidden variable in diagnostic pretest scores. American Journal of Physicd, 10, 1259-1268.

[34] Arikunto, S. (2010). Research procedure: a practical approach. (revised edition). Jakarta: Rineka Cipta.

[35] Supriatna, D., dan Mulyadi, M. (2009). The basic concept of learning design. Pusat Pengembangan dan Pemberdayaan Pendidik dan Tenaga Kependidikan Taman Kanak-kanak dan Pendidikan Luar Biasa. https://doi.org/10.31219/osf.io/z6jpx 
[36] Yunus, S. R., Sanjaya, I. G. M., Jatmiko, B. (2013). Implementasi Pembelajaran Fisika Berbasis Guided Inquiry untuk Meningkatkan Hasil Belajar Siswa Auditorik [Implementation of Physics Learning Based on Guided Inquiry to improve auditoric student learning outcome]. Jurnal Pendidikan IPA Indonesia, 2(1), 48-52. https://doi.org/10. 29408/jpek.v1i2.572

[37] Laurillard, D. (2012). Teaching as a design science: Building pedagogical patterns for learning and technology. New York, NY: Routledge.

[38] Kane, M.T. (2013). Validating the interpretations and uses of test scores. Journal of Educational Measurement, 50(1), 1-73. https://doi.org/10.1111/jedm.12000.

[39] Tsankov, N., Ivo D. (2019). The digital competence of future teachers: self-assessment in the context of their development. International Journal of Interactive Mobile Technologies (iJIM), 13(12), 4-18. https://doi.org/10.3991/ijim.v13i12.11068.

[40] Ormrod. (2009). Educational psychology: Developing learners (7th ed.). Upper Saddle River, NJ: Pearson-Prentice Hall.

[41] Morris, H. (2014). Socioscientific issues and multidisciplinarity in school science textbooks. International Journal of Science Education, 36(7), 1137-1158 https://doi.org/10.1080/ 09500693.2013 .848493

[42] Afify, M. K. (2019). The influence of group size in the asynchronous online discussions on the development of critical thinking skills, and on improving atudents' performance in online discussion forum. International Journal of Emerging Technologies in Learning (iJET), 14(5), 132-152. https://doi.org/10.3991/ijet.v14i05.9351

[43] Nasrullah, A. Mira, M., Widya, D. (2018). Development of student worksheet-based college e-learning through edmodo to maximize the results of learning and motivation in economic mathematics learning. International Journal of Emerging Technologies in Learning (iJET), 13(12), 211-229. https://doi.org/10.3991/ijet.v13i12.8636

\section{Authors}

Sri Wahyuni was a Lecturer, Researcher, at Universitas Jember, J1. Kalimantan III no 37 Jember 68121, Indonesia. She is now a Doctoral student at Universitas Negeri Surabaya, J1. Ketintang Surabaya 60231, Indonesia. Her interests include blended learning, quantitative analysis, and education technologies Email:sriwahyuni. fkip@unej.ac.id. ORCID Sri Wahyuni: http://orcid.org/0000-0002-0477-4455

Erman. Professor, Researcher, Universitas Negeri Surabaya, Jl. Ketintang Surabaya 60231, Indonesia. E-mail: erman@unesa.ac.id. ORCID Erman: http://orcid.org/00000002-8985-156X

Setya Yuwana Sudikan. Professor, Researcher, Universitas Negeri Surabaya, J1. Ketintang Surabaya 60231, Indonesia. E-mail: setyayuwana@unesa.ac.id.

Budi Jatmiko. Professor, Researcher, Universitas Negeri Surabaya, Jl. Ketintang Surabaya 60231, Indonesia. His interests include blended learning, quantitative analysis, and education technologies E-mail: budijatmiko@unesa.ac.id,bjbjatmiko2@gmail.com. ORCID Budi Jatmiko: http://orcid.org/0000-0003-2909-1121.

Article submitted 2020-01-06. Resubmitted 2020-03-06. Final acceptance 2020-03-08. Final version published as submitted by the authors. 